Гашимов С. Г., к.т.н., професор;

Байрамов А. А., д.ф.-м.н., професор

Військова Академія Збройних Сил Азербайджанської Республіки, Баку

\title{
Моделювання процесу виявлення невидимих військових об'сктів місцевості за допомогою БПЛА
}

Резюме. У статті представлено результати візуального моделювання процесу виявлення невидимих площ і військових об'єктів 3 точки спостереження обраної гірської місцевості Азербайджанської Республіки, з використанням БПЛА та програми Autodesk-3ds-max.

Ключові слова: бойові дії, невидима область, програма Autodesk-3ds-max, моделювання, безпілотний літальний апарат.

Постановка проблеми. Для успішного проведення військових операцій одним 3 найважливіших завдань $\epsilon$ виявлення невидимих військових об'єктів на місцевості. Для вирішення цього завдання, у тому числі, використовують безпілотні літальні апарати (БПЛА). Для якісного виконання розвідувальних завдань треба визначити раціональні розвідувальні маршрути, щоб запобігти знищенню супротивником власного БПЛА.

Аналіз останніх досліджень i публікацій. Умови спостереження є одними 3 тактичних вихідних даних, що впливають на організацію і проведення бойових операцій, на застосування бойової техніки $[1,2]$. Ці дані визначається ступенем видимості та дистанцією спостереження на місцевості, а також залежать від умов рельєфу. У результаті правильної організації спостереження отримана інформація дає можливість всебічно оцінити місце операції й прийняти правильне рішення. Чим більше на місцевості висот, схилів, ярів, дерев, чагарників і будівель, тим гірші умови спостереження. Здійснюючи спостереження в гірській місцевості необхідно вибрати таке місце, аби звідти можна було б бачити перевали, дороги, долини. Топографічні карти $є$ одним із джерел інформації про топографічні елементи місцевості (ix координати i взаємне розташування, розміри і т. п. кількісні та якісні характеристики). Проте на картах не відображаються елементи бойового порядку противника. Основним джерелом інформації про невказані на картах об'єкти $\epsilon$ аерофотознімки, отримані під час бойових дій. Ці фотознімки згодом можна використовувати в системах навігації високоточних озброєнь, наприклад різних видах кореляційнонавігаційних систем, 3 метою знищення невидимих мішеней противника [3]. Великі перешкоди (лісовий масив, високий пагорб, гори тощо) ще більше ускладнюють проблему і створюють необхідність використання безпілотного літального апарату (БПЛА) [4, 5]. Використання БПЛА, особливо безпілотних літаків, знайшло широке застосування в розвідувальних спостереженнях [6].

Метою статті $\epsilon$ висвітлення результатів візуального моделювання процесу виявлення невидимих площ і військових об'єктів 3 точки спостереження обраної гірської місцевості Азербайджанської Республіки з використанням БПЛА та програми Autodesk-3ds-max.

Виклад основного матеріалу. Метою вивчення умов спостереження $€$ визначення ступеня видимості та невидимості в зоні бойових дій з обраного пункту спостереження. Умови спостереження сприяють або погіршують ведення розвідки, організації системи вогню і управління підрозділами. Вони характеризуються показниками відстані прямої видимості 3 обраної висоти у відповідному секторі місцевості, а також розмірами і межами невидимих областей.

Порядок виявлення невидимих областей і мішеней на місцевості. Вивчення видимих i невидимих областей місцевості, використовуючи побудований профіль висот, виконується таким чином [7-11]. Обирається пункт спостереження на одній 3 висот. 3 цієї точки вздовж лівої і правої межі сектора спостереження проводяться дві прямі лінії. Сектор прямими лініями ділиться на кілька напрямків i позначається цифрами. Більш доцільно проведення цих ліній по вершинах висот або по лініях вододілу. Уздовж прямих ліній окремо або один під одним будуються профілі. Починаючи 3 точки спостереження, для кожного профілю визначаються невидимі області, які штрихуються. Ліві й праві межі 
заштрихованих

областей

повторно

відзначаються на карті вздовж ліній профілю.

Окреслені точки, враховуючи рельєф місцевості, з'єднуються суцільними лініями i невидимі області штрихуються олівцем на карті. У міру розширення сектора число ліній профілю збільшується і подовжується до необхідного місця.

Таким чином, уздовж заданих напрямків для виявлення видимих і невидимих областей будуть використані профілі місцевості. Висловлені міркування можна пояснити схемою на рис. 1 .

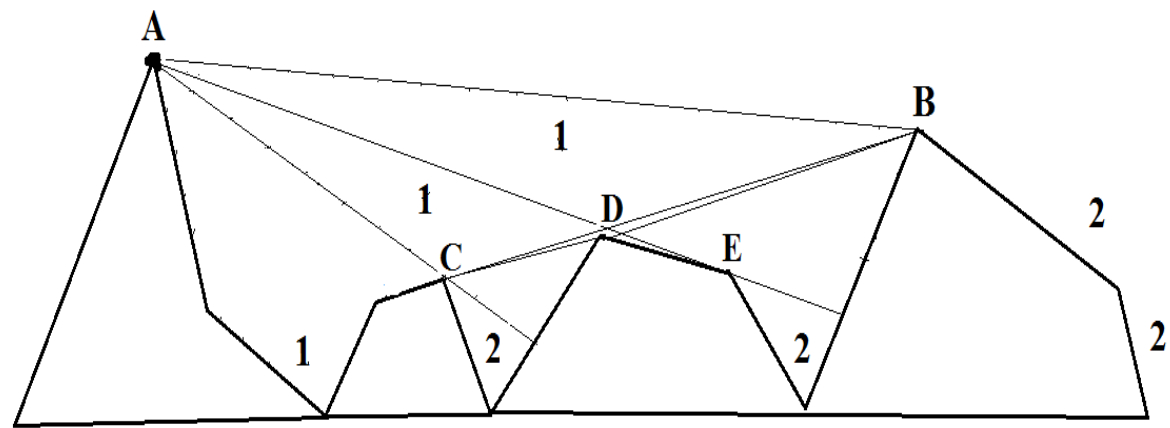

Рис. 1. Напрямки спостереження в одній з гірських місцевостей

На цьому рисунку умовно показана гірська місцевість. Виходячи 3 того, що: $A$ - обраний спостережний пункт на горі (або пагорбі), $\quad B$ - точка мішені (противника). Використовуючи технологію ГІС (географічна інформаційна система) на прямій лінії видимості у напрямку між точками $A$ i $B$ будуємо профіль висот. У результаті, виявляються видимі (1) і невидимі (2) області. Аналізуючи отриману інформацію на командному пункті в точці спостереження $A$ можуть дійти висновку, що якщо жива сила противника або бойова техніка буде розміщена в області (2), то вона не буде спостерігаєма. Якщо ж сили противника будуть знаходиться в області (1), то їх неможливо буде спостерігати з точки $A$.

Якщо пунктами спостереження будуть обрані точки $C$, або $D$, або $E$, тоді цим же способом можуть бути виявлені невидимі області: уздовж ліній $C D, D E$ або $E B$. Такі позиції спостереження можуть бути обрані в одній місцевості на різних вершинах. Для вірного прийняття рішення командир повинен вибрати таку точку спостереження, щоб сума невидимих областей була б мінімальною.

Для мінімізації ступеня невидимості місцевості можна використовувати БПЛА, направляючи його над точкою В $[7,12]$. Однак, можна стверджувати, що майже у всіх цих випадках БПЛА буде знищений. Для безпечного використання БПЛА його необхідно пілотувати недалеко від точки $A$ на такій висоті, щоб виявити невидимі з точки $A$ області, і щоб БПЛА не був би знищений противником.

Припустимо, що між точкою спостереження $A$ i точкою мішені $E$ розташовуються кілька висот (гірських вершин) (рис. 2).

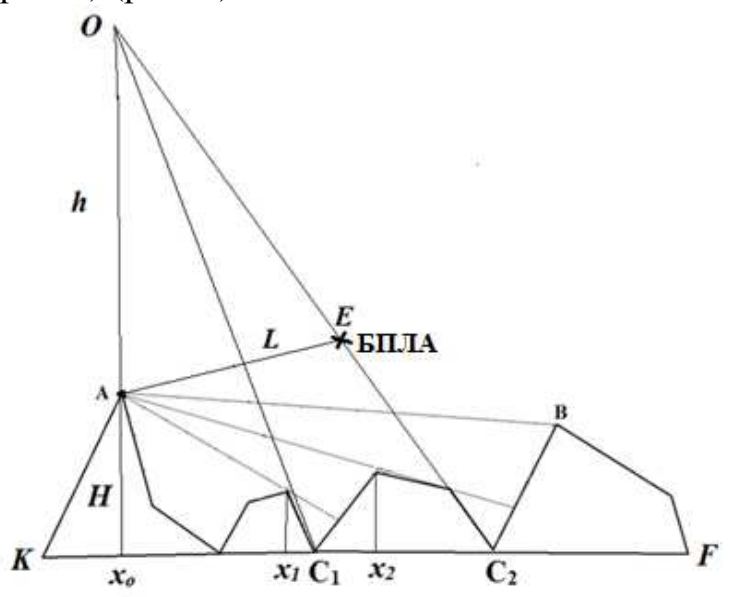

Рис. 2

Нехай

$\angle O C_{1} F=\alpha_{1}, \quad \angle O C_{2} F=\alpha_{2}, \ldots \quad \angle O C_{i} F=\alpha_{i}-$ кути схилів гірських вершин;

$H$ - висота точки спостереження;

$\mathrm{x}_{0}, \mathrm{x}_{1}, \mathrm{x}_{2}, \mathrm{x}_{i}$ - координати гірських вершин;

$h$-висота польоту БПЛА над точкою спостереження;

$O C_{i}$ - лінія, прокреслена від точки підйому БПЛА до дна гірського схилу $C_{i}$;

$L$ - відстань від точки $E$ польоту БПЛА до точки $A$.

Тоді нескладно отримати:

$$
\begin{gathered}
L \in\left\{h, x_{i}-x_{0}\right\}, \\
L=\sqrt{\left(x_{i}-x_{0}\right)^{2}-h_{i}^{2}}, \\
h_{i}=\left(x_{i}-x_{0}\right)\left(\left|\operatorname{tg} \alpha_{i}\right|-H\right) .
\end{gathered}
$$

Для здійснення контролю над невидимими областями, використовуючи формули (1), (2) i (3) можна визначити мінімальну безпечну висоту і відстань польоту БПЛА від точки $A$. 
Відзначимо, що величини $H, h, x_{o}$, $x_{1}, \ldots x_{i}$ та $\operatorname{tg} \alpha$ визначаються спеціалізованою програмою ГІС [7].

Результати візуального моделювання. Для візуального моделювання процесу виявлення невидимих областей i військових об'єктів на місцевості за допомогою БПЛА була використана програма Autodesk-3ds-max версії 2016 року [13]. Ця програма створена компанією Autodesk i широко використовується в усьому світі в різних областях для створення, редагування та анімації тривимірних графіків, вважається однією 3 найефективніших серед $3 \mathrm{~d}$ програм.

На рис. 3-6 показані результати візуального моделювання для однісї обраної гірській місцевості Азербайджанської Республіки.

На рис. 3 схематично показана ширина області огляду камери спостереження PUA в положенні над горами. Ширина кута огляду камери складає $130^{\circ}$.

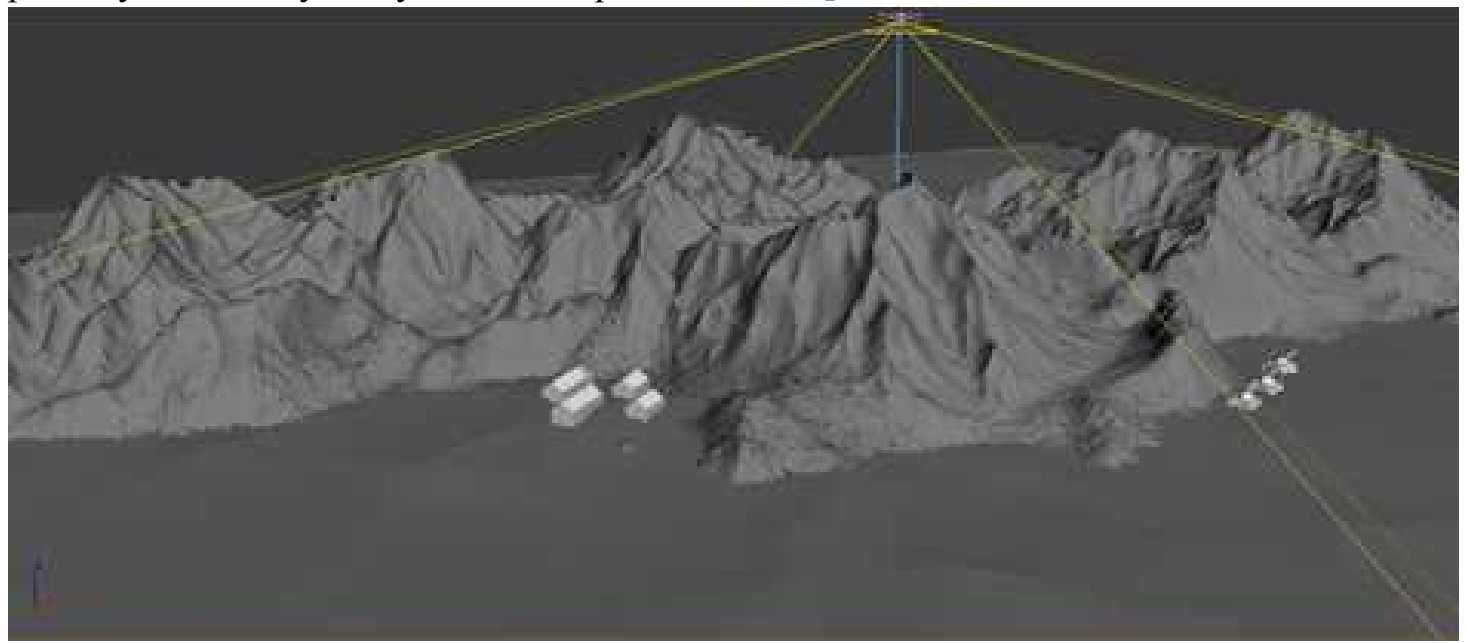

Рис. 3. Схематичне зображення ширини огляду камери спостереження БПЛА в положенні над горами

На рис. 4. показані результати візуального моделювання PUA у стартовому положенні на горі в точці спостереження.

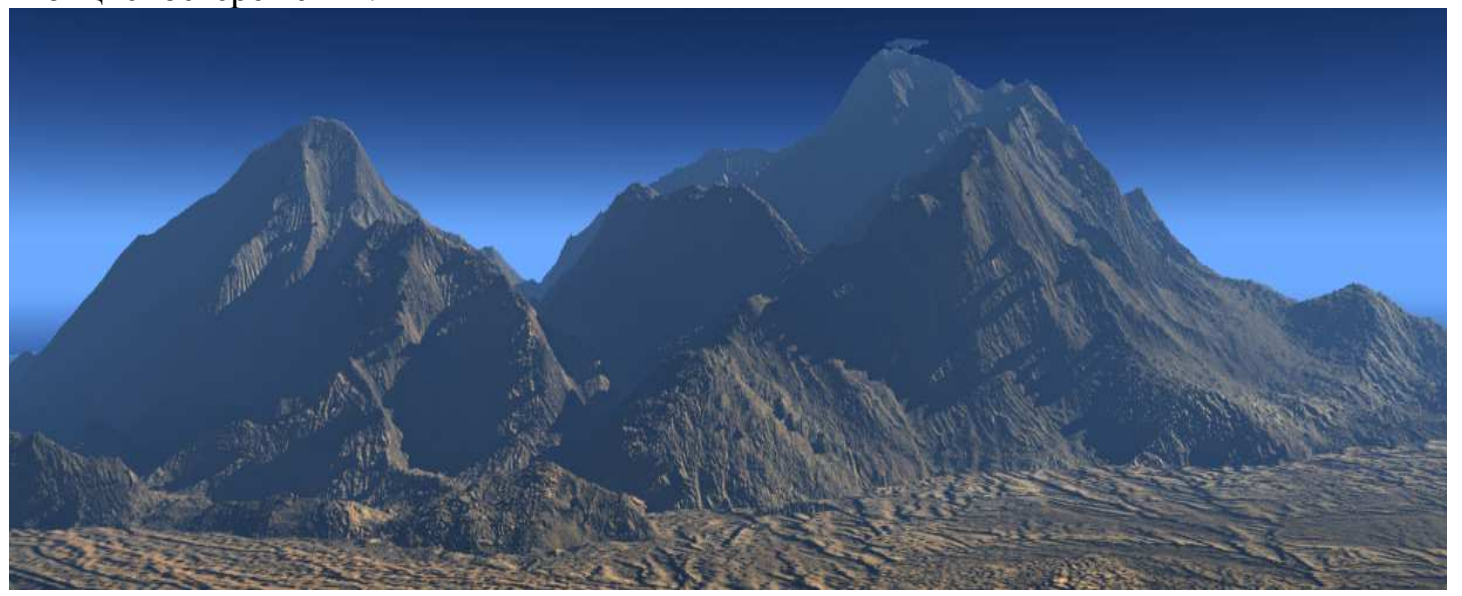

Рис. 4. Моделювання БПЛА в стартовому положенні на горі в точці спостереження

На рис. 5 показані результати моделювання PUA на висоті $h$ над стартовою точкою. Зеленим кольором позначені видимі 3 точки спостереження області, темним кольором - невидимі області.

На рис. 6 показані результати моделювання PUA на відстані $L$ від стартової точки. Зеленим кольором позначені видимі 3 точки спостереження області, темним кольором - невидимі області.

Як видно 3 рис 5, 6, чим вищий і довший політ PUA від пункту спостереження в бік противника, тим невидимих для спостерігачів областей стає менше. Тим самим менше стає ймовірність таємного пересування або укриття військової техніки супротивника.

Попереднє моделювання візуального огляду при польоті розвідувального PUA допоможе в реальній ситуації, для конкретної місцевості, точно визначити маршрут польоту PUA 3 метою максимального огляду місцевості, мінімізації невидимої площі та надійної ідентифікації прихованих об'єктів супротивника. 


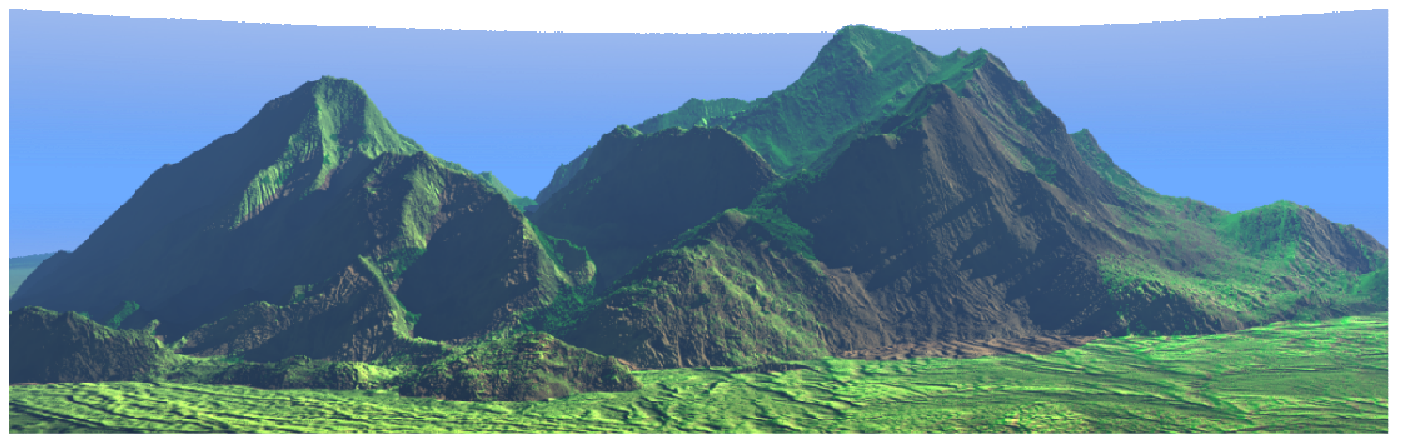

Рис. 5. Моделювання БПЛА на висоті $h$ над стартовою точкою

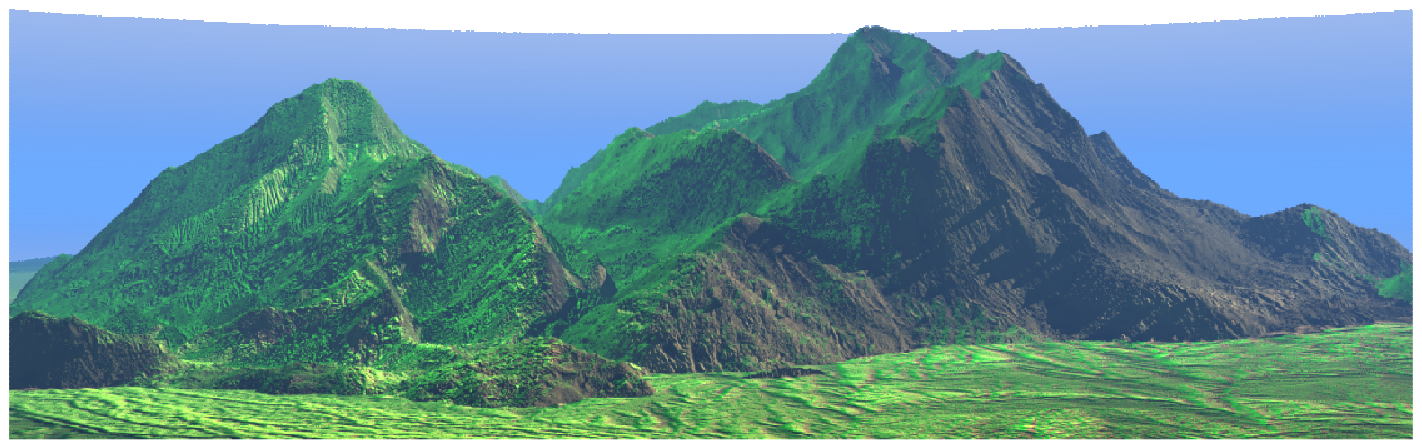

Рис. 6. Моделювання БПЛА на відстані L від стартової точки

Висновок. Таким чином, за допомогою програми Autodesk-3ds-max представлені та проаналізовані результати візуального моделювання процесу виявлення невидимих площ і військових об'єктів 3 точки спостереження обраної гірської місцевості Азербайджанської Республіки

3 використанням БПЛА. Доведено, що чим вище i далі політ БПЛА від пункту спостереження, тим невидимих для спостерігачів областей стає менше, збільшується ймовірність таємного пересування або укриття військової техніки супротивника.

Використання отриманих результатів у реальній ситуації дає можливість точно визначити маршрут польоту БПЛА 3 метою максимального огляду місцевості, мінімізації невидимої площі та надійної ідентифікації прихованих об' єктів супротивника.

\section{СПИСОК ВИКОРИСТАНОЇ ЛІТЕРАТУРИ}

1. Зарицкий В. Н., Харкевич Л. А. Общая тактика. ТГТУ, Тамбов, 2007, 94 с.

2. Piriyev G. K., Hashimov E. G., Bayramov A. A. Modelling of the battle operations. Monografiya, Herbi Nashriat", Baku, 2017, 250 p.

3. Hashimov E. G. About one method of navigation task solution // AHMC after H. Aliyev. Scientific Review, 2013. №1(20). pp. 45-49.

4. В. В. Бутин Дистанционно пилотируемые летательные аппараты как источник данных Д33 / “Геоматика". 2013, (3). - С. 24-27.

5. Е. А. Варварина Использование беспилотных летательных аппаратов для построения ортофотопланов линейных объектов / "Науки о Земле". 2012, (2). - С. 66-70. 
6. М. В. Петров Практический опыт использования БПЛА Swinglet Cam / Журнал "Геопрофи". 2013,(2). - C. 42-44.

7. Hashimov E. G. Bayramov A. A. Mathematical modeling of the tactics operations and battle dynamics // National security and military sciences. 2016, vol. 2, №1. - pp.13-25/

8. Hashimov E. G., Bayramov A. A., Xalilov B. M. Terrain orthophotoplanes making for military objects revealing // National security and military sciences. 2016, vol. 2, №4. - pp.14-20

9. Hashimov E. G., Bayramov A. A. The flight dynamics of drones // National security and military sciences. 2016, vol. 2, №3. - pp.11-16.

10. E. G. Hashimov, A. A. Bayramov, B. M. Khalilov Terrain orthophotomap making and combat control. Proceeding of Internatonal Conf. "Modern Call of Security and Defence". I-st vol.19-20 May 2016,
War College after G. Rakovski, Sofia. 2017. - p. 68$71 /$

11. Bayramov A. A., Hashimov E. G., Amanov R. R. Revealing of invisible objects of the terrain by use of GIS technology. Geography and nature resources, Reports of the Azerbaijan Geography Society, 2016, №1. - pp.124-126.

12. А. А. Байрамов, Э. Г. Гашимов Применение в БПЛА и сейсмолокационных станциях военного назначения композитных электретных элементов с нанопьезоэлектрической фазой. Proceeding of the V International scientific and practical conference "Modern problems of physics of metals". Azərbaycan Memarlıq və İnşaat Universiteti. 10-11 June 2016, Baku. - C. 297-300.

13. Autodesk 3ds-max visualization, simulation program. https://www.autodesk.com/products/3dsmax/overview.

Стаття надійшла до редакції 07.07.2017

Гашимов Е. Г., к.т.н., профессор;

Байрамов А. А., д.ф.-м.н., профессор

Военная Академия Вооружённых Сил Азербайджанской Республики, Баку

Моделирование процесса обнаружения невидимых военных объектов местности с помощью БПЛА

Резюме. В статье представлены результаты визуального моделирования процесса обнаружения невидимых площадей и военных объектов с точки наблюдения выбранной горной местности Азербайджанской Республики с использованием БПЛА и программы Autodesk-3ds-max.

Ключевые слова: боевые действия, невидимая область, программа Autodesk-3ds-max, моделирование, беспилотный летательный аппарат.

\section{E. Hashimov PhD, professor;}

A. Bayramov Dr. (Technical Sciences), professor

Military Academy of the Armed Forces of the Republic of Azerbaijan, Baku

Modeling the process of detecting invisible military objects of the terrain with the help of UAV

Resume: The article presents the results of visual modeling of the detection of invisible areas and military objects from the point of observation of the selected mountainous terrain of the Republic of Azerbaijan using UAV and Autodesk-3ds-max program. (UAV).

Keywords: fighting, invisible area, program Autodesk-3ds-max, simulation, unmanned aerial vehicle 